\title{
Medievalista
}

Online

$30 \mid 2021$

Número 30

\section{RUIZ PILARES, Enrique José - La sociedad política en Jerez de la Frontera a finales de la Edad Media. Cádiz: Editorial UCA, 2020 (274 pp.)}

Filipa Roldão

\section{(2) OpenEdition}

Journals

Edição electrónica

URL: https://journals.openedition.org/medievalista/4613

DOI: 10.4000/medievalista.4613

ISSN: 1646-740X

Editora

Instituto de Estudos Medievais - FCSH-UNL

\section{Refêrencia eletrónica}

Filipa Roldão, «RUIZ PILARES, Enrique José - La sociedad política en Jerez de la Frontera a finales de la Edad Media. Cádiz: Editorial UCA, 2020 (274 pp.)», Medievalista [Online], 30 | 2021, posto online no dia 01 julho 2021, consultado o 24 julho 2021. URL: http://journals.openedition.org/medievalista/4613 ; DOI: https://doi.org/10.4000/medievalista.4613

Este documento foi criado de forma automática no dia 24 julho 2021.

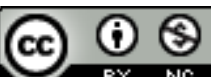

Mediavalista está licenciado com uma Licença Creative Commons - Atribuição-NãoComercial 4.0 Internacional. 


\title{
RUIZ PILARES, Enrique José - La sociedad política en Jerez de la Frontera a finales de la Edad Media. Cádiz: Editorial UCA, 2020 (274 pp.)
}

\author{
Filipa Roldão
}

\section{REFERÊNCIA}

RUIZ PILARES, Enrique José - La sociedad política en Jerez de la Frontera a finales de la Edad Media. Cádiz: Editorial UCA, 274 pp.

\section{NOTA DO EDITOR}

Data recepção do artigo / Received for publication: 2 de Abril de 2021

A obra La sociedad política en Jerez de la Frontera a finales de la Edad Media é fruto do trabalho de investigação doutoral do seu autor, Enrique José Ruiz Pilares, maturado pelos anos de reflexão que medeiam entre a defesa da tese, 2017, e a data da presente publicação, pela editora da Universidade de Cádiz, em 2020. Com prólogo de Emilio Martín Gutiérrez, a obra procura responder a uma pergunta central: como se caracterizava a sociedade política de Jerez de la Frontera na Baixa Idade Média, no que concerne à sua composição e ao seu funcionamento? Como o próprio autor afirma, o conceito de sociedade política é, aqui, central, não só porque posiciona a investigação sobre poderes urbanos numa vertente marcadamente social (por oposição a uma produção historiográfica mais atenta à caracterização institucional dos cargos de poder), como também porque explora a inteligibilidade de um conceito que, não sendo original, se revela, nesta obra, muito mais amplo e plural do que habitualmente é tratado. A capacidade do autor em potenciar o conceito de sociedade política relaciona- 
se directamente com a utilização cumulativa e cruzada de duas formas de percepção da participação política dos indivíduos, cuja génese se encontra em trabalhos de José María Monsalvo Antón e de José Antonio Jara Fuente: os processos de tomada de decisão, e o acesso aos recursos do poder, respectivamente. A partir destas duas abordagens, o autor propõe uma hierarquização da sociedade política de Jerez de la Frontera ao tempo dos Reis Católicos (1474-1504), demonstrando, com originalidade para o caso Andaluz, por um lado, que os poderes urbanos não se exercem apenas nos espaços do concelho, mas complementarmente também nas paróquias e no mercado, e, por outro, que esta sociedade política, cujos membros ocupam cargos ou lugares de decisão, se compõe de pelo menos quatro segmentos sócio-políticos: a elite concelhia, a elite paroquial, a elite dos comuns, e a comunidade ou povo. A partir da análise dos discursos e tomadas de decisão deixados por escrito e do método prosopográfico de análise relacional dos indivíduos e famílias - assente na colação e estudo de fontes tão diversas, como actas de reuniões concelhias e registos paroquiais -, o autor conseguiu identificar dinâmicas de elitização e de oligarquização no interior desta sociedade, proporcionando ao leitor não só um enfoque à escala familiar e individual, como também uma nítida imagem de conjunto de uma sociedade política compósita.

2 A estrutura central do livro é clara e esclarecedora quanto aos objectivos da investigação: após uma introdução geral à obra, a primeira parte dedica-se à identificação e estudo dos ofícios e dos espaços de poder, designadamente, o concelho e as paróquias, e a segunda parte procura reconstruir e compreender a sociedade política que lhe dá vida. $O$ autor inclui uma introdução a cada uma destas partes da obra, onde apresenta as principais questões a desenvolver, as metodologias usadas e os objectivos a alcançar. Vejamos com algum pormenor os diferentes capítulos que compõem estes dois grandes apartados em que a obra se divide. A primeira parte é composta por três capítulos: o primeiro é dedicado à natureza e composição social das reuniões concelhias, à época já restritas, onde se exercia o poder municipal por excelência, com enfoque para a presença de oficiais régios; o segundo visa compreender a participação concelhia de jurados e de deputados, representantes das paróquias da cidade; o terceiro é dedicado à caracterização de oficiais de gestão e justiça, onde se destacam os ofícios oriundos das paróquias, os ofícios do cabido, e os ofícios menores vitalícios.

3 A segunda parte é composta por quatro capítulos: o primeiro dedica-se à clarificação de algumas categorias sócio-políticas, de significado pouco definido na historiografia contemporânea; o segundo caracteriza as elites com representação no poder (elite concelhia e elite paroquial, e formação de linhagens); o terceiro aborda a composição social e profissional dos restantes vizinhos sem ligação às elites cavaleirescas, e ao poder, mas com peso sócio-económico - os homens comuns; o último capítulo é dedicado aos poderes externos com presença e influência na cidade e na vida pública, designadamente, a monarquia e a nobreza senhorial.

4 A reflexão do autor termina com as conclusões gerais da investigação, apontando os principais aspectos inovadores da obra no quadro historiográfico andaluz e até mesmo peninsular, e alguns dos caminhos futuros que o autor parece querer ainda percorrer no interior da medieva Jerez de la Frontera. Em seguida, é apresentado um extenso apartado de anexos - são trinta e três -, que serve de fundamentação heurística a todo o corpo da investigação, e que é mobilizado ao longo da obra, nos seus diferentes capítulos. Neste apartado, o autor colige os principais dados quantitativos e estatísticos sobre os quais assenta a sua reflexão (como, por exemplo, o número de ofícios 
desempenhados por família, o valor das rendas obtidas pela fazenda concelhia e o montante dos salários atribuídos), inclui informações de natureza descritiva (como excertos de discursos saídos das actas capitulares) e, de forma detalhada, mas de simples apreensão, expõe os resultados da metodologia prosopográfica, fornecendo os nomes dos indivíduos e/ou famílias que ocuparam lugares de poder assim como o modo de acesso aos mesmos, as datas de exercícios de ofícios, e o grupo sócio-político ou linhagem a que pertenciam. Outras compilações de dados e de análises relacionais são ainda fornecidas ao longo da obra - designadamente nove quadros, três mapas geotopográficos e três árvores genealógicas -, procurando estabelecer uma maior proximidade com o leitor. No entanto, uma futura inclusão destes objectos e ainda do Anexo final num índice descritivo de quadros e anexos ajudaria a localizar a informação de forma mais simples e a valorizar todas estas informações.

5 A obra termina com o elenco de arquivos e respectivos fundos consultados (ainda que sem referência às peças específicas consultadas) e com um extenso apartado com as referências bibliográficas da tese (onde o autor inclui também as fontes impressas utilizadas). No elenco bibliográfico, predominam, como seria de esperar, a referenciação exaustiva dos mais relevantes trabalhos peninsulares sobre poderes urbanos medievais, e onde o autor evidencia o diálogo com outras historiografias, nomeadamente, italiana, francesa e inglesa. A obra está disponível em edição em papel, e ainda em edição electrónica, que pode ser adquirida através do endereço electrónico das publicações da Universidade de Cádiz.

6 Enrique José Ruiz Pilares alcançou plenamente os objectivos a que se propôs nas páginas iniciais da obra, traçando um quadro compreensivo de uma sociedade política tardo-medieval andaluza a partir de abordagens diversificadas mas complementares, assente numa sólida pesquisa documental, e com aportações muito relevantes nos campos da definição terminológica de ofícios, no enfoque dado aos homens comuns e da comunidade na ocupação de posições de decisão representativa de partes substantivas da sociedade, no esclarecimento de mecanismos de acesso ao poder, na proposta concreta de hierarquização social. Jerez de la Frontera contém, a partir de agora, um estudo maturado sobre a sua sociedade política, incentivando o autor a continuar a reflectir, no futuro, sobre a sua composição e singularidade, e apresentando a possibilidade de comparação com outras cidades, ou, melhor, com outras sociedade políticas do Ocidente medieval.

\section{AUTORES}

\section{FILIPA ROLDÃO}

Universidade de Lisboa, Faculdade de Letras, Centro de História da Universidade de Lisboa, 1600-214 Lisboa. roldao.filipa@gmail.com. https://orcid.org/0000-0001-8760-6133 